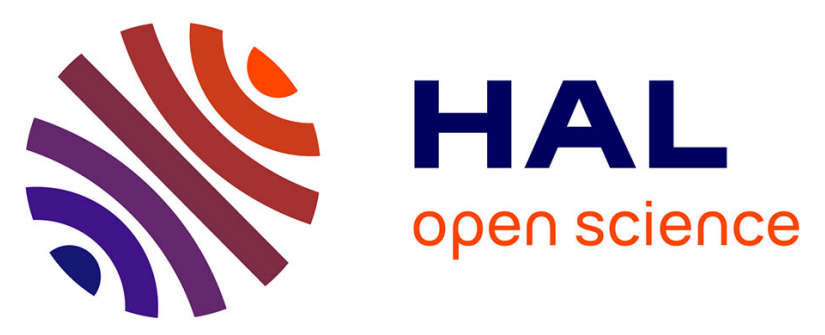

\title{
Amphibole CPO in retrograded gabbro from the Lyngen Magmatic Complex (Northern Scandinavian Caledonides, Norway).
}

Marina Galindos Alfarache, Holger Stünitz, Jiří Konopásek, Amicia Lee

\section{To cite this version:}

Marina Galindos Alfarache, Holger Stünitz, Jiří Konopásek, Amicia Lee. Amphibole CPO in retrograded gabbro from the Lyngen Magmatic Complex (Northern Scandinavian Caledonides, Norway).. vEGU21: Gather Online, Apr 2021, Online, France. 10.5194/egusphere-egu21-1303 hal-03554567

\author{
HAL Id: hal-03554567 \\ https://hal.science/hal-03554567
}

Submitted on 3 Feb 2022

HAL is a multi-disciplinary open access archive for the deposit and dissemination of scientific research documents, whether they are published or not. The documents may come from teaching and research institutions in France or abroad, or from public or private research centers.
L'archive ouverte pluridisciplinaire HAL, est destinée au dépôt et à la diffusion de documents scientifiques de niveau recherche, publiés ou non, émanant des établissements d'enseignement et de recherche français ou étrangers, des laboratoires publics ou privés.

\section{(c)(1)}

Distributed under a Creative Commons Attribution| 4.0 International License 
EGU21-1303

https://doi.org/10.5194/egusphere-egu21-1303

EGU General Assembly 2021

(c) Author(s) 2022. This work is distributed under

the Creative Commons Attribution 4.0 License.

\title{
Amphibole CPO in retrograded gabbro from the Lyngen Magmatic Complex (Northern Scandinavian Caledonides, Norway).
}

\author{
Marina Galindos Alfarache ${ }^{1}$, Holger Stünitz ${ }^{1,2}$, Jiří Konopásek ${ }^{1}$, and Amicia Lee ${ }^{1}$ \\ ${ }^{1}$ Dept. of Geosciences, UiT The Arctic University of Norway, Tromsø, Norway (marina.galindos@uit.no) \\ ${ }^{2}$ Institut des Sciences de la Terre (ISTO), Université d'Orléans, Orléans, France
}

Deformation of natural mafic rocks by viscous deformation mechanisms can occur even at low temperature conditions. In such instances, crystal plastic mechanisms are not operative, as their activity is restricted to very high temperatures for amphiboles, pyroxenes, and plagioclase. Instead, simultaneous mineral reactions may facilitate deformation at low temperature conditions. The gabbro from the Lyngen Magmatic Complex (LMC) constitutes a good example of such processes, because it has experienced deformation at low temperatures of greenschist to lower amphibolite-facies conditions, and the rock has been transformed from gabbro to greenschist. This study focuses on detailed analysis of deformation processes, metamorphic reactions and fabric development in the LMC gabbro. Most samples are overprinted by epidote amphibolite and greenschist-facies mineral assemblages. Preliminary observations distinguish two different types of amphiboles, which have been interpreted as different generations. The predominant type defines the stretching lineation and shows long prismatic habits whereas the less abundant type crystallized in a sub- to anhedral manner. The metamorphic conditions of growth for each amphibole type is yet not well constrained. However, we initially interpret the former to grow during epidote amphibolite- or greenschist facies-conditions, whereas the latter could represent relict grains from the original magmatic assemblage or products generated at amphibolite- or epidote amphibolite-facies conditions. Further analysis will determine the orientation, geochemistry and metamorphic conditions during growth for both amphibole types. A recent model proposed for eclogites suggests that simultaneous mineral growth and deformation can result in new products growing in a preferred direction. Such preferential growth can generate a shape preferred orientation parallel to the lineation, which results in the formation of crystal preferred orientations (CPO). We aim to test if similar microstructural observations can be translated to the amphiboles of the LMC gabbro. In such case, amphibole CPO's would not be the product of crystal plasticity but of preferential growth. The large scale deformation of the LMC emphasizes the relevance of these results, as it would demonstrate that the interaction between mineral reactions and deformation can play a major role on regional deformation of large mafic bodies, such as the ocean floor. 